\title{
In Vivo Analysis of Therapeutic Effects of Hydroxychloroquine, Azithromycin, Paracetamol, Dexamethasone, Remdesivir and Tocilizumab in Patients Affected with Novel Covid-19
}

\author{
UMAIR WAQAS (corresponding author) \\ Lecturer, Department of Allied Health Sciences, University Of Lahore Chenab Campus \\ PO box 50700 Gujrat, Punjab, Pakistan \\ NAZEEHA WASEEM (co-author) \\ Medical Imaging Doctor, Department of Radiological sciences and Medical imaging, University of Lahore \\ Pakistan. \\ ABID ALI (co-author) \\ Associate Professor, Department of Allied Health Sciences, University of Lahore Chenab Campus \\ SAQIB NADEEM (co-author) \\ Department of life sciences, University of management and technology, Lahore Pakistan
}

\begin{abstract}
COVID 19 creates pandemic around the globe. This virus spread so rapidly and unfortunately till now there is no authentic treatment available. Based upon the trials various drugs were applied to control the disease. Different drugs found effective including hydroxychloroquine, dexamethasone, azithromycin and remdesivir. In current study 100 patients were participated. The presence of disease was confirmed by PCR based tests. Initials reports represent various abnormal range of WBC's in patients. Most of them were symptomatic while few were asymptomatic. Gender wise COVID-19 mostly affected males rather than female gender. It was also found that older person were more susceptible than younger one.Effectiveness of the drugs shows there is need to do more work on following components to control the disease prevalence until a vaccine is discovered.
\end{abstract}

Keywords: COVID-19, Dexamethasone, SARS

DOI: $10.7176 / \mathrm{JHMN} / 81-06$

Publication date:October $31^{\text {st }} 2020$

\section{INTRODUCTION}

Coronavirus disease 2019 (COVID-19) is a disease caused by severe acute respiratory syndrome coronavirus, more precisely beta family of coronaviruses type 2 (SARS-CoV-2) which primary occured in Wuhan, the capital city of Hubei provenance in China rapidly evolved into a global pandemic infecting million with no country spared.(1,2) A few new cases of atypical pneumonia were firstly detected by health authorities in Wuhan in late December. Further research and genetic sequencing detected RNA virus which is part of the Coronavirus family, the same family of the virus which caused Severe Acute Respiratory Distress Syndrome known as SARS in 2003 and Respiratory Syndrome of Middle East known as MERS in 2012 . There is around $80 \%$ of genetic similarity between SARS-CoV and SARS-CoV-2 and occupying angiotensin-converting enzyme 2 (ACE2) receptors is considered for now the primary mechanism of how SARS-CoV-2 invades human cells. $(1,3)$

In spite of the that it is well confirmed that COVID-19 is first and foremost respiratory infection, considerable data emerge that COVID-19 should be also considered as a systemic infection, which involves multiple organs systems, such as cardiovascular, neurological, hematopoietic and gastrointestinal.(4) New evidence emerge that not only older people and those with comorbidities are at increased risk of serious complication or lethal outcome but younger population without significant underlying disease might also experience very serious complications such as disseminated vascular coagulopathy (DIC) or fulminant myocarditis.(4)

A considerable piece of research shows that SARS-CoV-2 leads to "cytokine storm" causing activation of coagulation cascade causing thrombosis which compromises the blood supply of organs.(5) Haematological study of COVID-19 patients while patients are in incubation period (1-14 days) and at the early phase of COVID-19, shows that leukocytes and lymphocytes are usually normal or slightly reduced, while later on when clinical manifestations become more evident significant lymphopenia occurs. As lymphocytes express ACE2 receptors on their surface, the possible mechanism of lymphopenia is that SARS-CoV-2 directly binds to these cells causing lysis of these cells.(5,6) In addition, the main feature of cytokine storm is increased concentrations of interleukins, mainly IL-2, IL-6, IL-7, TNF- $\alpha$ (tumor necrosis factor-alfa) which promote apoptosis of lymphocytes. Furthermore, cytokine storm might be related to atrophy of the spleen and lymphoid organs which 
additionally has a negative impact turnover of lymphocytes.(5) Number of drugs until now have been tested against the virus. With large number of potential therapeutics, the goal is to test the efficiency and safety of these drugs. This study is a comparative analysis of Hydroxychloroquine, Azithromycin, Dexamethasone, Remdesivir and Tocilizumab on the outcome in patients affected with COVID-19.

\section{MATERIALS AND METHODS}

All the patients with lab-confirmed COVID-19 infection admitted to the emergency department of Aziz Bhatti Shaheed Hospital, (DHQ) Gujrat in province Punjab Pakistan between 2 April and 2 may 2020. Positive lab test for SARS-Cov-2 was depicted as a result of RT-PCR analysis.

We have further divided the patients in sub categories of symptomatic, asymptomatic, male, and female and three age based groups.

\section{Data Collection}

On the basis of certain variables, patients were being evaluated. The recorded data comprises of the following: Age, Gender, complete blood count (CBC), renal function tests, Serum electrolytes, and Coagulation tests.

\section{Statistical Analysis}

The data was analysed by excel tool with sum and subtraction approach. The data is being illustrated in the pie charts.

\section{GENERAL CHARACTERIZATION OF THE PATIENTS}

In current study patients were analysed by PCR based diagnosis method. The study population comprises hundred patients having confirmed COVID-19. Out of these 100 patients $81 \%$ of a population were symptomatic while $19 \%$ asymptomatic.

This study showed covid-19 suffering patients had $61 \%$ male while $39 \%$ were females.

The median age of the patients ranges from 30 to 90 years old.

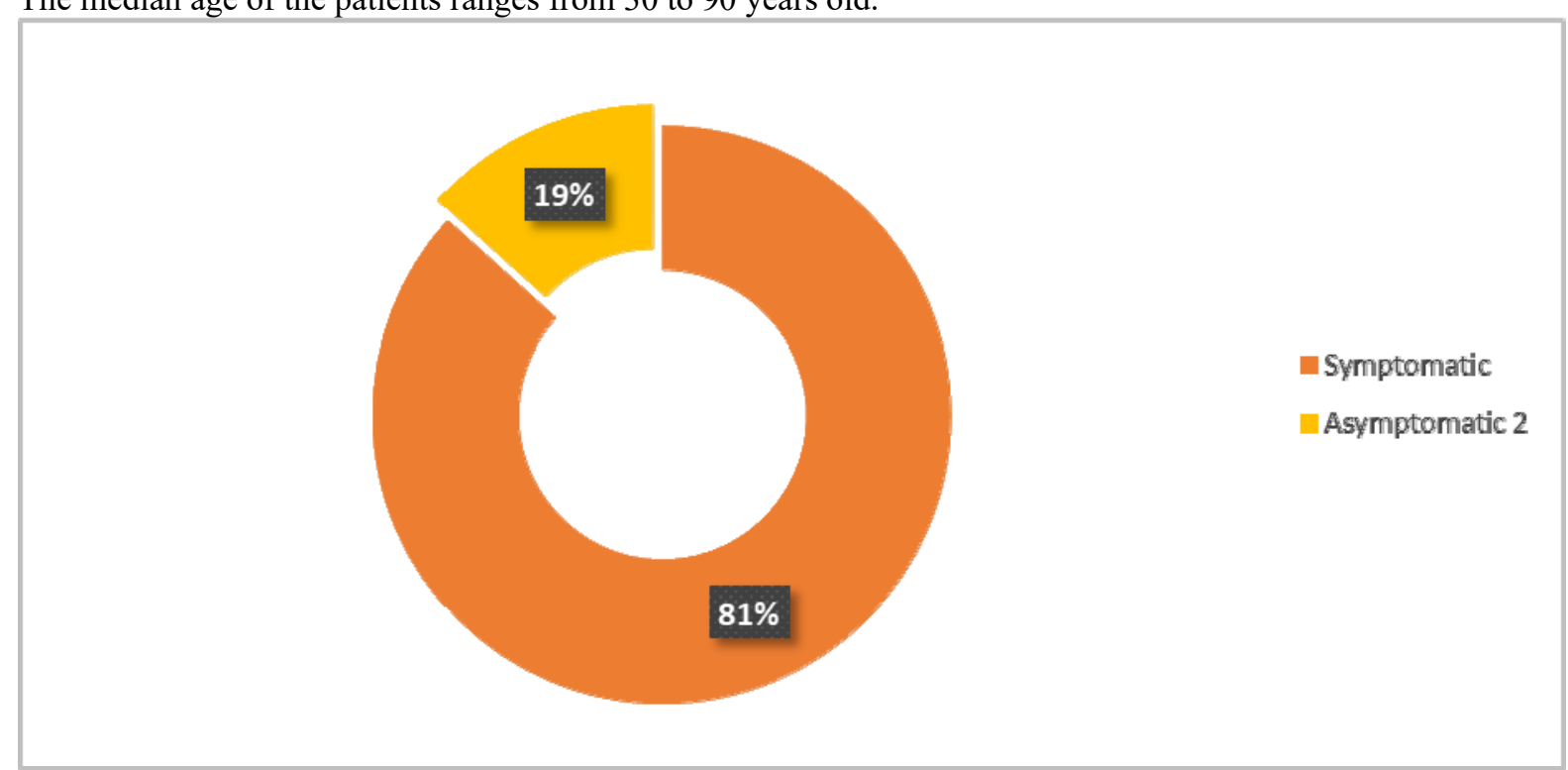

\section{Clinical Presentation of Patients}

The symptomatic patients have combination of symptoms varying in each patient. Fever was the most common and frequent symptom in patients. $17.2 \%$ of total symptomatic patients had fever with no any other symptom. $20 \%$ of symptomatic patient had shortness of breath, fever along with coughing while $13.58 \%$ reported to have sore throat along with shortness of breath and fever.

$11.11 \%$ had fever along with cough and other details are mentioned in the table above. Fever, cough, sore throat, and shortness of breath were the main highlighted symptoms among covid-19 suffering patients. Other mild symptoms include Myalgia, dry cough, body ache anorexia and shortness of breath. 


$\begin{array}{lcc}\text { Symptoms } & \text { No. of Patient } & \text { Percentage } \\ \text { FEVER } & 14 & 17.2 \% \\ \text { COUGH } & 2 & 2.47 \% \\ \text { COUGH+BODY ACHE } & 2 & 2.47 \% \\ \text { COUGH+SOB } & 2 & 2.47 \% \\ \text { DRY COUGH } & 2 & 2.47 \% \\ \text { FEVER+COUGH } & 9 & 11.11 \% \\ \text { FEVER+DRYCOUGH } & 6 & 7.40 \% \\ \text { FEVER+MYALGIA } & 1 & 1.2 \% \\ \text { FEVER+SORE THROAT } & 11 & 13.58 \% \\ \text { SOB } & 4 & 4.93 \% \\ \text { SOB, ANOREXIA, FEVER, BODYACHE } & 7 & 8.64 \% \\ \text { SOB,COUGH } & 2 & 2.47 \% \\ \text { SOB, FEVER } & 9 & 11.11 \% \\ \text { SOB, FEVER+COUGH, ANOREXIA } & 2 & 2.47 \% \\ \text { SOB+ FEVER+COUGH } & 8 & 9.87 \% \\ \text { SOB+ARDS } & 1 & 1.2 \%\end{array}$

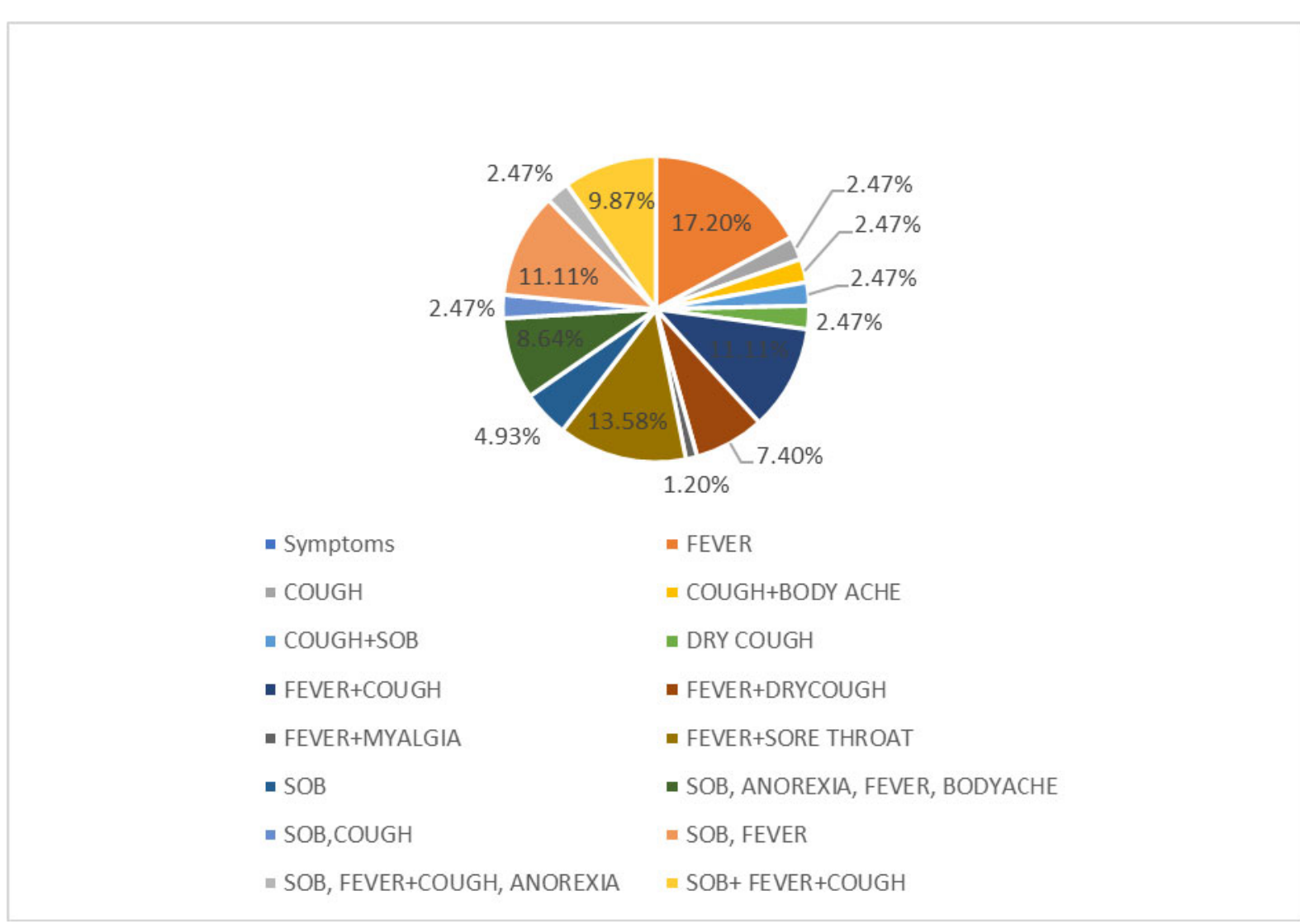

Initial Report Results

Initial reports of patients represent that white blood cells count of patients of age group 30 was 3.9 to 7.9 In age group 30 to 60 years was 4.1 to 6.8 and in patients belonging to age group 60 to 90 years the value ranged from 2.99 to 12.43 . 
Further details of their reports are given in the table below.

\begin{tabular}{|l|l|l|l|}
\hline & Age 30 & Age 30 to 60 & Age 60 to 90 \\
\hline WBC(*10^9/l) & $3.9-7.9$ & $4.1-6.8$ & $2.99-12.43$ \\
\hline Lymphocytes & $1.41-3.41$ & $1.90-3.19$ & $0.7-1.54$ \\
\hline Granulocytes & $1.5-6.13$ & $1.6-6.10$ & $1.49-11.34$ \\
\hline Platelets (*10^9/l) & $108-314$ & $120-155$ & $108-173$ \\
\hline RBC (*10^12/l) & $4.8-5.28$ & $3.83-5.6$ & $3.83-4.64$ \\
\hline Hb (g/dl) & $9.1-13.3$ & $8.9-13.9$ & $7.4-14.1$ \\
\hline Na(mmol/l) & $130-145$ & $135-145$ & $136-147$ \\
\hline K(mmol/l) & $3.9-5.9$ & $3.10-6.5$ & $3.11-6.8$ \\
\hline S/Creatinine (mg/dl) & $0.7-1.3$ & $0.8-1.3$ & $0.9-1.8$ \\
\hline B/Urea (mg/dl) & $22-41$ & $23-84$ & $20-202$ \\
\hline APTT(sec) & $26-35$ & $28-37$ & $34-45$ \\
\hline PT (sec) & $13-16$ & $13-16$ & $13-18$ \\
\hline INR & $1.0-1.15$ & $1.1-1.20$ & $0.9-1.3$ \\
\hline Ca (mmol/l) & $9.1-10.12$ & $9.6-10.9$ & $9.9-11$ \\
\hline Ph & $2.1-8.5$ & $2.1-8.3$ & $2.1-9.2$ \\
\hline Age-Related Amalysis & & & \\
\hline
\end{tabular}

\section{Age-Related Analysis}

To explore the impact of age with covid-19 the population was stratified into three major groups. Age group 30 or less than 30. Second group ranges from 30 to 60 years old and third group patients ranges from 60 to 90 years old.

Major signs and laboratory results were not much verified between age groups however where comparable the results indicated, old patients had a higher proportion covid-19 as compared to the younger patients.

$50 \%$ of the patients had age range 30 to 60 years while $30 \%$ were from age group 60 to 90 years and $20 \%$ of the study sample was less than 30 years old. Which clearly revealed that older age people are more susceptible to have covid-19 as compared to the younger ones.

Treatment Details

The treatment combination of HCQ, Azithromycin and Paracetamol was not given to a group of 30 years old patients while eight patients from group of 30 to 60 years old and four patients from age group 60-90 received this combination of drugs.

Paracetamol+ Risek+ HCQ as treatment was given to two patients from age group 30 and four patients from age from 30 to 60. Amodil, Azithromycin and Surbex were given to one patient separately only, belonging to age group 60-90.

The Combinations of lowplat+ Clexane, Aspirin+Risek, Acefyl+Fexet+Paracetamol, Dexamethasone+Paracetamol+Insulin, Diazepam+Dexamethasone, Aspirin+Risek were given to patients from age group 60-90. The rest of details of further medications along with combinations has been given in table

\section{Column1}

PARACETAMOL

PARACETAMOL+LOPRIN

PARACETAMOL+OMEGA+REMDESIVIR+LOPRIN

PARACETAMOL+RISEK+HYDROXYCHLOROQUINE

PARACETAMOL+RISEK

PARACETAMOL+RISEK +AZYTHROMYCIN+HEPAMERS

PARACETAMOL+TONOFLEX+HEPAMERS

PARACETAMOL+ACEFYL

PARACETAMOL+ACEFYL+EZIDAY

PARACETAMOL+EZIDAY+HCQ+RISEK

PARACETAMOL+EZIDAY+RISEK

PARACETAMOL+RISEK + CIPROFLOXACIN+GRAVID

RISEK+MYRIN P FORTE

RISEK+VANCOMYCIN

SURBEX

TOCILIZUMAB+DEXAMETHASONE

ACEFYL+FEXET+PARACETAMOL

AMODIL

AZYTHROMYCIN

$\begin{array}{ccc}\text { Age } & \begin{array}{c}\text { Age } \mathbf{3 0} \text { to } \\ \mathbf{3 0}\end{array} & \begin{array}{c}\text { Age } \mathbf{6 0} \text { to } \\ \mathbf{9 0}\end{array} \\ 8 & 6 & 3 \\ 0 & 1 & 0 \\ 0 & 1 & 0 \\ & & \\ 2 & 4 & 1 \\ 1 & 1 & 0 \\ 0 & 1 & 0 \\ 0 & 1 & 0 \\ 0 & 2 & 0 \\ 0 & 1 & 0 \\ 0 & 1 & 0 \\ 0 & 1 & 0 \\ 0 & 1 & 0 \\ 1 & 0 & 0 \\ 0 & 1 & 0 \\ 0 & 0 & 1 \\ 0 & 4 & 6 \\ 1 & 2 & 0 \\ 0 & 1 & 0 \\ 0 & 1 & 1\end{array}$




\section{Column1}

DEXAMETHASONE+ PARACETAMOL+INSULIN

DIAZEPAM+ DEXAMETHASONE

ASPIRIN+RISEK

HCQ+FLAGEL+NOSPA+RISEK

HCQ+PARACETAMOL

HCQ+PARACETAMOL+AZYTHROMYCIN

HCQ+RISEK+HYDRALINE

HEPARIN+CLEXANE

INSULIN+PARACETAMOL+RISEK

LOPRIN

LOWPLAT+CLEXANE

MOXIFLOXACIN+AZYTHROMYCIN+PARACETAMOL+RISE K

\section{MULTIBIONTA}

After treatment with the above mentioned medications the reports of patients revealed that $\mathrm{WBC}$ of age group 30 ranges from 3.8 to 7.9. While the patients of age group 30-60 has WBC 2.95-9.57 and patients from age group 60 to 90 has WBC range 2.95-9.57.

\begin{tabular}{|c|c|c|c|c|c|c|c|c|c|c|c|}
\hline TREATMENT & AGE & WBC $\left({ }^{*} 10^{\wedge} 9 / 1\right)$ & Lymphocytes & Granulocytes & Platelets & $\begin{array}{l}\mathrm{Hb} \\
(\mathrm{g} / \mathrm{dL})\end{array}$ & $\mathrm{Na}(\mathrm{mmol} / \mathrm{l})$ & $\mathrm{K}(\mathrm{mmol} / \mathrm{l})$ & S/Creatinine & B/Urea & APTT(sec) \\
\hline \multirow[t]{3}{*}{ PARACETAMOL } & $<=30$ & $3.81-7.9$ & $0.38-2.98$ & $2.05-5.28$ & $247-346$ & $9.5-13.8$ & $130-142$ & $3.6-6.9$ & $0.7-4.3$ & $20-92$ & $29-37$ \\
\hline & 30 to 60 & $3.95-8.54$ & $0.38-4.24$ & $1.50-7.97$ & $119-480$ & $8.9-13.8$ & $130-142$ & $3.2-6.9$ & $0.6-4.3$ & $21-92$ & $23-36$ \\
\hline & 60 to 90 & $2.95-9.57$ & $0.38-4.24$ & $2.13-4.66$ & $119-447$ & $8.9-13.2$ & $130-142$ & $3.8-6.9$ & $0.7-4.3$ & $20-92$ & $28-36$ \\
\hline \multirow[t]{3}{*}{ PARACETAMOL+RISEK+HCQ } & $<=30$ & $2.24-6.21$ & $0.75-1.54$ & $3.38-4.11$ & $108-253$ & $8.8-11.8$ & $135-136$ & $4.3-4.8$ & $0.8-1.2$ & $31-202$ & $25-34$ \\
\hline & 30 to 60 & $2.24-6.97$ & $0.75-2.4$ & $2.18-4.11$ & $108-259$ & $8.8-15.2$ & $135-141$ & $4.3-4.8$ & $0.8-1.2$ & $24-202$ & $31-33$ \\
\hline & $60-90$ & 12.43 & 0.7 & 11.34 & 141 & 11.7 & 145 & 6.2 & 1.4 & 38 & 30 \\
\hline \multirow[t]{2}{*}{ PARACETAMOL+RISEK } & $<=30$ & 16.2 & 2.2 & 13.7 & 198 & 14.1 & 137 & 3.9 & 1.1 & 19 & 31 \\
\hline & 30 to 60 & 7.83 & 1.80 & 5.05 & 253 & 13.7 & 140 & 3.8 & 0.9 & 20 & 32 \\
\hline RISEK+MYRIN P FORTE & $<=30$ & 19.01 & 0.93 & 17.51 & 104 & 11.9 & 149 & 3.4 & 1 & 23 & 36 \\
\hline AMODIL & 30 to 60 & 13.49 & 0.59 & 12.28 & 259 & 12.1 & 139 & 5.6 & 1.1 & 47 & 39 \\
\hline \multirow[t]{2}{*}{ AZYTHROMYCIN } & 30 to 60 & 28.3 & 2.1 & 17 & 372 & 11 & 144 & 3.1 & 0.9 & 53 & 17 \\
\hline & 60 to 90 & 14.8 & 1 & 13.28 & 241 & 13.1 & 123 & 4.7 & 1.4 & 76 & 38 \\
\hline \multirow[t]{2}{*}{ PARACETAMOL+FEXET+ACEFYL } & $<=30$ & 5.84 & 1.51 & 2.91 & 347 & 13.2 & 137 & 6.2 & 1.5 & 46 & 33 \\
\hline & 30 to 60 & $4.79-9.57$ & $2.71-3.76$ & $1.68-4.86$ & $215-409$ & $11.6-14$ & $135-142$ & $4.2-4.3$ & $1.1-1.3$ & $31-34$ & $30-33$ \\
\hline $\begin{array}{l}\text { DEXAMETHASONE+PARACETAMOL } \\
\text { +INSULIN }\end{array}$ & 60 to 90 & 16.2 & 2.1 & 7.3 & 259 & 8.09 & 123 & 3.7 & 1.5 & 47 & 41 \\
\hline DIAZEPAM+DEXAMETHASONE & 60 to 90 & 18.1 & 0.82 & 7.9 & 355 & 8.5 & 130 & 4.8 & 1.7 & 78 & 49 \\
\hline ASPIRIN+RISEK & 60 to 90 & 14.85 & 1.51 & 6.1 & 223 & 15.7 & 138 & 5.8 & 1.6 & 28 & 55 \\
\hline HCQ+FLAGEL+NOSPA+RISEK & $<=30$ & 3.83 & 1.55 & 2.99 & 337 & 13.0 & 140 & 4.0 & 0.9 & 26 & 32 \\
\hline \multirow[t]{3}{*}{ HCQ+PARACETAMOL } & $<=30$ & $3.81-7.6$ & $3.8-2.86$ & $2.05-4.81$ & $347-426$ & $\begin{array}{ll}10.5- \\
13.6\end{array}$ & $132-141$ & $3.5-6.8$ & $0.7-1.8$ & $24-42$ & $29-35$ \\
\hline & $30-60$ & $3.85-9.25$ & $0.31-4.21$ & $1.25-7.91$ & $260-496$ & $\begin{array}{l}10.5- \\
14.1\end{array}$ & $132-143$ & $3.7-6.9$ & $0.8-1.9$ & $26-49$ & $28-36$ \\
\hline & $60-90$ & $4.79-8.12$ & $2.16-3.02$ & $1.67-3.96$ & $385-409$ & $\begin{array}{l}12.9- \\
14.1 \\
\end{array}$ & 133-143 & $4.2-4.7$ & $1.1-1.5$ & $37-52$ & $32-45$ \\
\hline \multirow[t]{2}{*}{$\begin{array}{l}\text { HCQ+PARACETAMOL } \\
\text { +AZYTHROMYCIN } \\
\end{array}$} & 30 to 60 & $2.36-7.94$ & $0.65-4.12$ & $3.10-4.26$ & $245-426$ & $\begin{array}{l}11.5- \\
13.9\end{array}$ & 134-137 & $3.9-4.2$ & $0.9-1.2$ & $22-49$ & $29-35$ \\
\hline & 60 to 90 & $7.4-9.5$ & $2.16-3.01$ & $1.59-3.20$ & $247-358$ & $9.5-12.5$ & $130-143$ & $3.6-6.9$ & $0.7-4.8$ & $36-52$ & $31-47$ \\
\hline HCQ+RISEK+HYDRALINE & 30 to 60 & 6.78 & 2.13 & 4.79 & 314 & 13.8 & 137 & 4.0 & 1.1 & 27 & 37 \\
\hline HEPARIN+CLEXANE & 30 to 60 & 6.26 & 0.63 & 5.26 & 299 & 7.4 & 147 & 3.8 & 1.6 & 32 & 58 \\
\hline $\begin{array}{l}\text { INSULIN+PARACETAMOL+RISEK } \\
\end{array}$ & 30 to 60 & 4.23 & 1.88 & 2.07 & 248 & 11.6 & 137 & 4.8 & 1.7 & 22 & 30 \\
\hline LOPRIN & 30 to 60 & 12.31 & 0.63 & 11.63 & 358 & 8.3 & 140 & 4.1 & 1.6 & 43 & 64 \\
\hline LOWPLAT+CLEXANE & 60 to 90 & 10.3 & 1.2 & 12.8 & 296 & 15.5 & 138 & 3.4 & 1.9 & 67 & 98 \\
\hline \multirow[t]{2}{*}{$\begin{array}{l}\text { MOXIFLOXACIN+AZYTHROMYCIN } \\
\text { +PARACETAMOL +RISEK }\end{array}$} & 30 to 60 & 4.52 & 0.65 & 3.02 & 554 & 8.2 & 141 & 3.2 & 0.6 & 20 & 34 \\
\hline & $60-90$ & 4,75 & 1.1 & 2.20 & 396 & 12.5 & 139 & 3.9 & 0.6 & 41 & 39 \\
\hline MULTIBIONTA & $<=30$ & 18.03 & 0.5 & 17.27 & 83 & 10.9 & 150 & 4.1 & 1.6 & 68 & 122 \\
\hline PARACETAMOL+LOPRIN & 30 to 60 & 2.99 & 0.71 & 1.49 & 173 & 7.4 & 137 & 3.8 & 1.2 & 22 & 31 \\
\hline $\begin{array}{l}\text { PARACETAMOL } \\
+ \text { +OMEGA+REMDESIVIR+LOPRIN } \\
\end{array}$ & 30 to 60 & 3.48 & 0.06 & 1.79 & 328 & 10.7 & 141 & 4.9 & 0.9 & 47 & 32 \\
\hline $\begin{array}{l}\text { PARACETAMOL +RISEK+MONTIKA } \\
\end{array}$ & 60 to 90 & 12.43 & 0.7 & 11.34 & 141 & 11.7 & 145 & 6.2 & 1.4 & 38 & 30 \\
\hline $\begin{array}{ll}\text { PARACETAMOL } & \text { +RISEK } \\
+ \text { +AZYTHROMYCIN+HEPAMERS } & \end{array}$ & 30 to 60 & 6.01 & 2.59 & & 318 & 14.2 & 141 & 3.5 & 1.1 & 28 & 30 \\
\hline $\begin{array}{l}\text { PARACETAMOL } \\
+ \text { +TONOFLEX+HEPAMERS }\end{array}$ & 30 to 60 & 5.21 & 1.29 & 3.49 & 173 & 13.5 & 139 & 3.7 & 0.9 & 20 & 30 \\
\hline PARACETAMOL+ACEFYL & 30 to 60 & 2.24-9.57 & $0.75-4.24$ & $3.38-4.66$ & $253-447$ & $\begin{array}{l}10.5- \\
11.8\end{array}$ & $135-136$ & $3.9-4.3$ & $0.8-0.9$ & $31-41$ & $31-32$ \\
\hline PARACETAMOL+ACEFYL+EZIDAY & 30 to 60 & 6.97 & 1.85 & 2.18 & 259 & 15.2 & 140 & 4.6 & 1 & 24 & 31 \\
\hline PARACETAMOL+EZIDAY+HCQ+RISEK & 30 to 60 & 3.48 & 0.06 & 1.79 & 328 & 10.7 & 141 & 4.9 & 0.9 & 47 & 32 \\
\hline PARACETAMOL+EZIDAY+RISEK & 30 to 60 & 4.52 & 0.65 & 3.02 & 554 & 8.2 & 141 & 3.2 & 0.6 & 20 & 34 \\
\hline $\begin{array}{l}\text { PARACETAMOL+RISEK } \\
+ \text { +CIPROFLOXACIN+GRAVID }\end{array}$ & 30 to 60 & 6.21 & 1.54 & 4.11 & 108 & 8.8 & 136 & 4.8 & 1.2 & 45 & 31 \\
\hline \multirow[t]{2}{*}{ TOCILIZUMAB+DEXAMETHASONE } & $30-60$ & $3.142-8.65$ & $0.34-4.10$ & $1.49-7.27$ & $220-475$ & $8.6-13.6$ & $130-143$ & $3.2-6.8$ & $0.6-4.2$ & $22-62$ & $28-36$ \\
\hline & $60-90$ & $3.84-6.75$ & $0.75-4.21$ & $3.39-4.52$ & $245-401$ & $\begin{array}{ll}10.6- \\
12.3\end{array}$ & 134-137 & $4.1-4.3$ & $0.8-0.9$ & $31-45$ & $27-36$ \\
\hline RISEK+VANCOMYCIN & 30 to 60 & 7.21 & 0.86 & 5.86 & 274 & 9.2 & 144 & 3.8 & 0.7 & 45 & 38 \\
\hline SURBEX & 60 to 90 & 13.45 & 0.97 & 12.13 & 281 & 12.5 & 135 & 4.2 & 1.1 & 39 & 65 \\
\hline
\end{tabular}

\section{Discussion}

The current study involved the hundred patients suffering from covid-19 in Gujrat, Punjab Pakistan. The clinical signs and symptoms of patients indicated that Age, Gender and Medication were the most common factors in the progression of disease. 
In this study the median age of patients was 30-60 years that was in line with the study conducted in China where median age was reported 65.8 years old.(7) These results indicated that the progression in age is a major factor in occurrence of covid-19. As according to Mei $\mathrm{J}$, et al there is greater intensity of prevailing this disease in males as compared to females. Our results showed the same trend of results that male persons are more susceptible to get infected with SARS-coV2 infection than females (8) The reason behind this phenomenon is not fully explained yet. Fever was the most common symptom observed in patients suffering from covid-19. $(9,10)$ The major supportive therapy was given to the patients as a combination of drugs that are mentioned above. The major effective combination of drugs include: Azithromycin, Paracetamol, Hydroxychloroquine, Remdesivir, Tocilizumab, and Dexamethasone. The usage of this combination of drugs proved to give a speedy effect as a recovery of COVID effected patients. Moreover the positive effect of these drugs was clearly evident in the laboratory reports of the effected patients.

\section{Conclusion}

Most of the patients being severely affected with covid-19 infection were male with the age more than 60 years and they presented with certain symptoms as mentioned above. Among all of these the fever, cough and shortness of breath were most common symptoms in these patients. The most effective therapeutic drugs against the majorly effected patients of COVID-19 were PARACETAMOL, TOCILIZUMAB, AZITHROMYCIN, HYDROCHLOROQUINE, and REMDESIVIR.

\begin{tabular}{|c|c|c|}
\hline Gender & Percentage & No. of Pt. \\
\hline Male & $61 \%$ & 61 \\
\hline Female & $39 \%$ & 39 \\
\hline
\end{tabular}

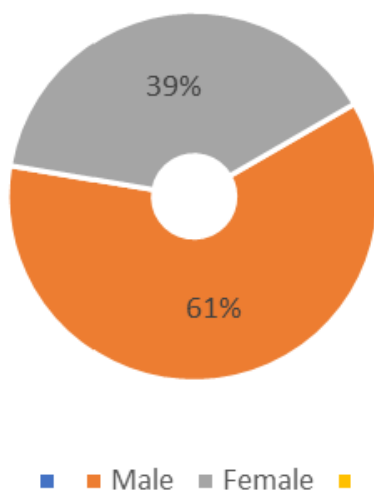

\section{References}

1. Ortiz-Prado E, Simbaña-Rivera K, Gomez-Barreno L, Rubio-Neira M, Guaman LP, Kyriakidis N. Clinical, Molecular and Epidemiological Characterization of the SARS-CoV2 Virus and the Coronavirus Disease 2019 (COVID-19): A Comprehensive Literature Review. 16 de abril de 2020 [citado 18 de abril de 2020].

2. Shanker, A., 2020. The Possible Origins of the New Coronavirus SARS-CoV-2.

3. Lu R, Zhao X, Li J, Niu P, Yang B, Wu H, Wang W, Song H, Huang B, Zhu N, Bi Y. Genomic characterisation and epidemiology of 2019 novel coronavirus: implications for virus origins and receptor binding. The Lancet. 2020 Feb 22;395(10224):565-74.

4. Terpos E, Ntanasis-Stathopoulos I, Elalamy I, Kastritis E, Sergentanis TN, Politou M, Psaltopoulou T, Gerotziafas G, Dimopoulos MA. Hematological findings and complications of COVID-19. American journal of hematology. 2020 Apr 13.

5. Menezes-Rodrigues FS, Padrão Tavares JG, Pires de Oliveira M, Guzella de Carvalho R, Ruggero Errante P, Omar Taha M, Fagundes DJ, Caricati-Neto A. Anticoagulant and antiarrhythmic effects of heparin in the treatment of COVID-19 patients. Journal of Thrombosis and Haemostasis. 2020 May 14.

6. Xu H, Zhong L, Deng J, Peng J, Dan H, Zeng X, Li T, Chen Q. High expression of ACE2 receptor of 2019$\mathrm{nCoV}$ on the epithelial cells of oral mucosa. International journal of oral science. 2020 Feb 24;12(1):1-5.

7. Du Y, Tu L, Zhu P, et al. Clinical features of 85 fatal cases of COVID-19 from Wuhan: a retrospective observational study. Am J Respir Crit Care Med. 2020; 201:1372-1379 https://doi.org/ 10.1164/rccm.202003-0543OC

8. Chen R, Wenhua L, Mei J, et al. Risk factors of fatal outcome in hospitalized subjects with coronavirus disease 2019 from a nationwide analysis in China. Chest. 2020;20:79. 
https://doi.org/10.1016/j.chest.2020.04.010

9. Badawi A, Ryoo SG. Prevalence of comorbidities in the Middle East respiratory syndrome coronavirus (MERS-CoV): a systematic review and meta-analysis. Int J Infect Dis. 2016;49:129-133.

10. Channappanavar R, Fett C, Mack M, Ten Eyck PP, Meyerholz DK, Perlman S. Sex-based differences in susceptibility to severe acute respiratory syndrome coronavirus infection. J Immunol. 2017;198(10): 40464053 